\title{
Provenance changes in fine detrital quartz in the inner shelf sediments of the East China Sea associated with shifts in the East Asian summer monsoon front during the last 6 kyrs
}

\author{
Ke Wang ${ }^{1,2^{*}}$, Ryuji Tada ${ }^{1,2,3}$, Hongbo Zheng ${ }^{2}$, Tomohisa Irino ${ }^{4^{*}}$, Bin Zhou $^{5}$ and Keita Saito ${ }^{1}$
}

\begin{abstract}
The inner shelf sediments of the East China Sea (ECS) preserve valuable information regarding climatic changes on land through detrital material discharged from large rivers, particularly the Yangtze River. In this paper, we examine the provenance changes of fine-grained detrital quartz preserved in the sediment of the MD06-3040 core retrieved from the mud belt on the inner shelf of the ECS during the last 6 kyrs. The provenance of the fine silt fraction (4$16 \mu \mathrm{m}$ ) of the sediments, which is considered to represent the suspended particulate matter (SPM) from the Yangtze River, is estimated based on the electron spin resonance (ESR) signal intensity and crystallinity index (Cl) of quartz. By comparing the ESR signal intensity and $\mathrm{Cl}$ of quartz in the fine silt fraction of sediments to those from different parts of tributaries in the modern Yangtze River drainage, we can discriminate the SPM sourced from the northwestern and southeastern tributaries of the Yangtze River. Shifts in the East Asian summer monsoon (EASM) front are monitored by changes in the main precipitation areas which are manifested as changes in source rock ages and types implied from the ESR signal intensity and $\mathrm{Cl}$ of quartz in the fine silt fraction of the studied sediments discharged from the Yangtze River. Temporal changes in provenance of the fine silt fraction through time suggest that shifts in the main location of EASM precipitation (most likely representing the EASM front) occurred at a multi-centennial-to-millennial scale with the deepest northwestward penetration of the EASM precipitation front (an enhanced EASM) occurring during the period 3.5-2.0 kyr BP and a southeastward retreat (a weak EASM) occurring during the periods 6.0-4.1 and 2.0-0 kyr BP.
\end{abstract}

Keywords: Electron spin resonance, Crystallinity index, East Asian summer monsoon, The Yangtze River drainage, The East China Sea

\section{Introduction}

The East Asian summer monsoon (EASM) is a distinctive component of the Asian climatic system due to unique orographic forcing and huge thermal contrast between the world's largest continent, Eurasia, and the largest ocean, the Pacific (Zhou et al. 2009). It is also strongly influenced by the world's highest land feature, the Tibetan Plateau

\footnotetext{
* Correspondence: wangke@eps.s.u-tokyo.ac.jp; irino@ees.hokudai.ac.jp ${ }^{1}$ Department of Earth and Planetary Science, The University of Tokyo, Tokyo, Japan

${ }^{4}$ Faculty of Environmental Earth Science, Hokkaido University, Sapporo, Japan Full list of author information is available at the end of the article
}

(Wang and Lin 2002; Wang et al. 2002; Ding and Chan 2005; Tada et al. 2016). Meteorological data suggest that modern EASM precipitation shows significant spatiotemporal variability in eastern and southern China at a seasonal timescale, which has been attributed to the seasonal northwestward migration of its precipitation front (Zhang et al. 2008; Yim et al. 2014; Tada et al. 2016). Comparison of the observational precipitation amount to the strength of convection over East Asia suggests that summer precipitation increases (decreases) in North China and decreases (increases) in South China when convection over East Asia strengthens (weakens) (Wang et al. 2002; Ding 
and Chan 2005). As the trend of precipitation derived from observational data represents a limited length of time and spatial extent, the main purpose of this study was to reconstruct spatiotemporal variations of the main location of EASM precipitation within the Yangtze River drainage during the middle and late Holocene.

Among various monsoon proxy records, oxygen isotope records of stalagmites $\left(\delta^{18} \mathrm{O}_{c}\right)$ from South China have been widely used because of the precise dating of the records using U-series method and its quantitative nature with high time resolution (Wang et al. 2001, 2005; Hu et al. 2008; Cheng et al. 2006). Early works interpret stalagmite $\delta^{18} \mathrm{O}$ signals as representing changes in the summer/winter precipitation ratio (Wang et al. 2001) whereas later works interpret it as a proxy for regional precipitation of the EASM, with higher EASM precipitation corresponding to depleted (more negative) $\delta^{18} \mathrm{O}_{\mathrm{c}}$ (Wang et al. 2005). Namely, shifts in $\delta^{18} \mathrm{O}_{\mathrm{c}}$ largely reflect changes in the oxygen isotope ratio of precipitation $\left(\delta^{18} \mathrm{O}_{\mathrm{p}}\right)$ at the site, which in turn reflect changes in the amount of precipitation (the so-called amount effect) and thus characterize the EASM precipitation intensity (Wang et al. 2005). However, these interpretations have been recently questioned. For example, Maher and Thompson (2012) suggested that changes in the oxygen isotope ratio of these stalagmites in South China do not necessarily represent the amount effect but rather represent changes in the source of water vapors. Furthermore, when stalagmites occur along the edge of monsoonal belts, their oxygen isotope ratios could be impacted by both the EASM and Indian summer monsoon (ISM). One needs to carefully consider regional, geographical, and seasonal effects and in particular consider the amount-weighted $\delta^{18} \mathrm{O}$ (Maher 2008; Maher and Thompson 2012).

By using the $\delta^{18} \mathrm{O}$ and $\mathrm{Mg} / \mathrm{Ca}$ of planktonic foraminifera, Kubota et al. $(2010,2015,2019)$ reconstructed the $\delta^{18} \mathrm{O}$ of surface water $\left(\delta^{18} \mathrm{O}_{\mathrm{sw}}\right)$ in the northern East China Sea (ECS), which is an indirect indicator of the sea surface salinity (SSS). Using the relationship between the SSS in the northern ECS and the Yangtze River discharge during summer, Kubota et al. $(2010,2015)$ reconstructed temporal changes in the Yangtze River summer discharge during the Holocene, which they consider as the proxy of EASM precipitation in South China. They argued that their result inferred from $\delta^{18} \mathrm{O}_{\mathrm{sw}}$ is not consistent with $\delta^{18} \mathrm{O}_{c}$ records of stalagmites in South China that implied the early Holocene EASM precipitation maximum. Thus, they suggested that it is not appropriate to explain orbital-scale changes in stalagmite $\delta^{18} \mathrm{O}_{\mathrm{c}}$ in South China during the Holocene by changes in the EASM precipitation amount, but more appropriate to explain the changes by other factors such as changes in the moisture source (Kubota et al. 2015).
The provenance of sediment as well as paleoenvironmental changes on the inner shelf of the ECS have been well studied (Zheng et al. 2010; Wang et al. 2014; Liu et al. 2014; Yang et al. 2015; Bi et al. 2017; Fang et al. 2018; Liu et al. 2018). In this study, we conducted provenance discrimination using the electron spin resonance (ESR) signal intensity and crystallinity index (CI) of quartz, which has been successfully applied to modern surface samples to trace eolian dusts from various deserts in western China (Sun et al. 2007, 2013), to core sediment recovered from the Japan Sea to trace dust provenance changes in association with the southward-northward shifts of the Westerly Jet (WJ) (Nagashima et al. 2007, 2011, 2012, 2013) and to characterize suspended particulate matter (SPM) collected from various segments of the Yangtze River drainage (Saito et al. 2017). Saito et al. (2017) established a new method to evaluate relative contribution of sediment discharge from different parts of the Yangtze drainage basin based on the provenance of quartz in the fine silt fraction (4$16 \mu \mathrm{m})$ of riverbed sediments collected from all the major tributaries of the Yangtze River using ESR signal intensity and CI of quartz as a provenance tracer. They concluded that the changes in provenance of the fine silt fraction of detrital material are caused by changes in the high-precipitation area between the upper reaches and the middle-lower reaches (Saito et al. 2017). The Yangtze River drainage basin occupies the major part of South China in the middle of the present EASM region. The annual precipitation ranges from $500 \mathrm{~mm}$ in the west to $2500 \mathrm{~mm}$ in the east, and greater than $60 \%$ of the annual precipitation is concentrated during summer (June, July, and August) (Xu et al. 2008). Because SPM constitutes more than $95 \%$ of the sediment load discharged from the Yangtze River (Chen et al. 2001), and a strong positive relationship $\left(R^{2}=0.81\right)$ exists between sediment load and fresh water discharge (Xu et al. 2010), fresh water discharge of the Yangtze River could reflect precipitation amounts in the drainage (Chen et al. 2014). Consequently discharge of SPM from the Yangtze River could reflect precipitation amounts in the drainage. Based on these observations, changes in the SPM provenance reflect changes in the distribution of highprecipitation areas (Saito et al. 2017). The SPM discharged from the Yangtze River, whose grain size is dominantly a fine silt size, is distributed on the inner shelf of the ECS extending southwestward from the Yangtze River estuary along the southeastern coast of South China, forming mud belts (Qin 1979; Qin et al. 1987; Liu et al. 2007). Based on this reasoning, we applied the provenance discrimination method of Saito et al. (2017) to the MD06-3040 core retrieved from the mud belt on the inner shelf of the ECS to reconstruct spatiotemporal variations in the EASM precipitation area 
within the Yangtze River drainage during the middle and late Holocene by examining provenance changes of fine detrital quartz $(4-16 \mu \mathrm{m})$ derived from the Yangtze River.

\section{Regional setting}

The inner shelf of the ECS is of primary importance owing to the massive inputs of terrestrial materials from the Yangtze River, among the largest rivers in the world in terms of sediment load and freshwater discharge (Milliman and Meade 1983; Milliman et al. 1985; Milliman and Syvitski 1992), and its complex oceanic circulation on the shallow $(<130 \mathrm{~m})$ and broad $(500 \mathrm{~km})$ shelf (Qin 1979; Qin et al. 1987). Although annual sediment load decreased from $0.48 \times 10^{9} \mathrm{t} /$ year during the $1960 \mathrm{~s}$ to $0.34 \times 10^{9} \mathrm{t} /$ year during the $1990 \mathrm{~s}$ due to dam construction and water consumption, the Yangtze River remains the predominant sediment supplier to the delta and coastal areas (Milliman and Meade 1983; Milliman et al. 1985; Milliman and Syvitski 1992). In contrast, sediment contribution from the Qiantang, Min, $\mathrm{Ou}$, and Jiao rivers to the coastal areas is only $0.007 \times 10^{9}$, $0.006 \times 10^{9}, 0,003 \times 10^{9}$, and $0.001 \times 10^{9} \mathrm{t} /$ year, respectively (Deng et al. 2006).
Two major types of sediments have been recognized as Yangtze-River-derived sediments on the inner shelf of the ECS system: mud-dominated sediments and the relict sandy sediments deposited during the Late Pleistocene low-sea-level stands (Qin 1979; Qin et al. 1987). The mud-dominated sediments predominantly discharged from the Yangtze River as SPM were mainly carried by the Zhejiang-Fujian Coastal Current (ZFCC) flowing south to southwestward along the Chinese coast, forming the mud belt on the inner shelf of the ECS. The warm and saline Taiwan Warm Current (TWC), which partly originates as an offshoot of the Kuroshio Current, flows northeastward between the 50 and $100 \mathrm{~m}$ isobaths of the ECS and intrudes into the submerged river valley off the Yangtze River mouth. The warm and saline Kuroshio Current (KC) enters the ECS along the eastern coast of Taiwan and the mainstream flows northeast along $200 \mathrm{~m}$ isobaths (Fig. 1) (Yang et al. 1992; Chen et al. 1994; Chang and Isobe 2003; Liu et al. 2007; Wang et al. 2014).

According to previous stratigraphic and seismic profiling studies (Liu et al. 2006, 2007; Liu et al. 2014; Wang et al. 2014), the depositional sequence in the tidedominated Yangtze delta and mud belt areas is composed of a post-glacial transgressive surface (TS) and

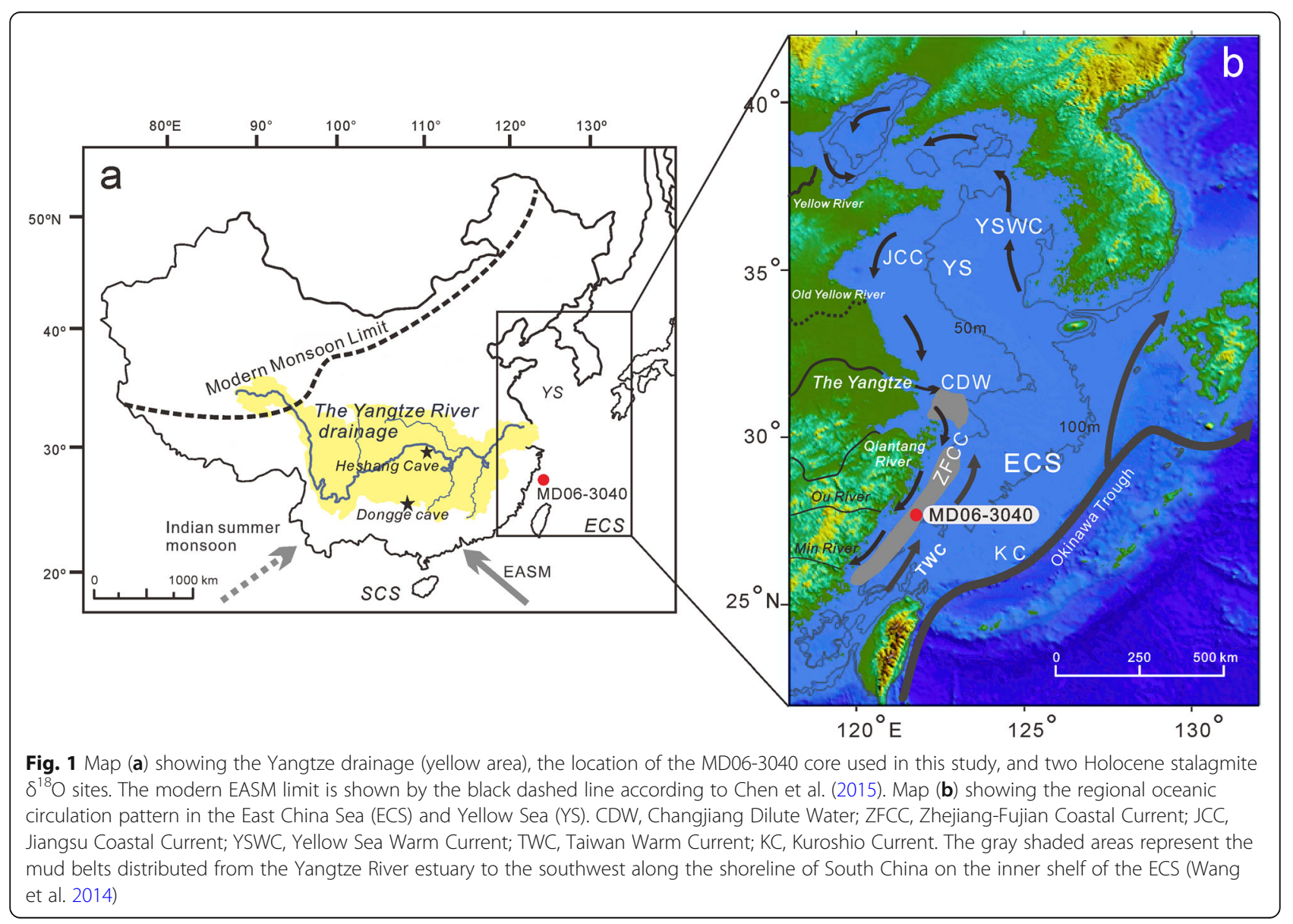


transgressive systems tract (TST) that are overlain by the subsequent highstand systems tract (HST) with the maximum flooding surface (MFS) at its base (Liu et al. 2007).

\section{Methods}

\section{Materials}

The MD06-3040 core was recovered from the central mud belt off the Zhejiang-Fujian coast on the inner shelf of the ECS $\left(27^{\circ} 43.36^{\prime} \mathrm{N}, 121^{\circ} 46.88^{\prime} \mathrm{E}\right)$ at a water depth of $47 \mathrm{~m}$ during the IMAGES MD155-Marco Polo cruise II by R/V Marion Dufresne in 2006 (Wang et al. 2014). The division of lithostratigraphic units of the MD063040 core is described in Wang et al. (2014). Stratigraphic correlation between the two neighboring cores MD06-3039 (27 $\left.43.36^{\prime} \mathrm{N}, 121^{\circ} 46.91^{\prime} \mathrm{E}\right)$ and MD063040 was conducted based on visual pattern matching and cross-correlation of the magnetic susceptibility profiles, which enabled us to project the age-controlling datums of the MD06-3039 core to the MD06-3040 core (Wang et al. 2014). Using this common stratigraphic framework established between the MD06-3039 and MD06-3040 cores, the age model for MD06-3040 core was constructed using nine $\mathrm{AMS}^{14} \mathrm{C}$ dates of bivalve shells, five shell samples obtained from MD06-3039 core, and four from the MD06-3040 core (Wang et al. 2014). To increase the precision of the age model, an additional four well-preserved shells from the MD063040 core were analyzed at Paleo-Labo Co., Ltd., to revise the previous age model (Kajita et al. 2018). All AMS ${ }^{14} \mathrm{C}$ dates were converted to calendar years using the Oxcal v 4.2.4 software (Ramsey and Lee 2013) with the Marine 13 dataset (Reimer et al. 2013), which includes a constant average global reservoir age of 400 years (Kajita et al. 2018, Table 1).
One-hundred and thirty samples at a stratigraphic interval of $4 \mathrm{~cm}$ (sometimes 8 or $16 \mathrm{~cm}$ due to sample deficiency) from the MD06-3040 core were analyzed for the ESR signal intensity and CI of quartz in the fine silt fraction to reconstruct provenance changes of the SPM discharged from the Yangtze River at a 40-year interval on average. The analyzed samples include 84 samples analyzed by Wang et al. (2014), who used the ESR signal intensity and CI of quartz to distinguish between Yangtze-derived sediment and sediments derived from other local rivers. The remaining 86 samples are newly analyzed in this work.

\section{ESR signal intensity analysis}

The ESR signal intensity of the $\mathrm{E}_{1}{ }^{\prime}$ center in the quartz reflects the number of unpaired electrons accompanied by oxygen vacancies (Feigl et al. 1974; Toyoda and Ikeda 1991; Toyoda and Naruse 2002). As oxygen vacancies are formed mainly by $\alpha, \beta$, or $\gamma$ rays emitted by natural radiation of radioactive elements contained in the host rock, the ESR signal intensity increases with an increase in the age of the host rock (Toyoda and Naruse 2002). The ESR signal intensity of the bulk sample was normalized by the weight percent of quartz in the sample to obtain the ESR signal intensity of the quartz per unit weight, whose unit is $1.3 \times 10^{15} \mathrm{spins} / \mathrm{g}$ (Toyoda and Hattori 2000).

Prior to ESR signal intensity measurement, a pretreatment sequence for the sample is necessary to concentrate quartz grains and remove elements such as $\mathrm{Mn}$ that interfere with $E_{1}{ }^{\prime}$ center signal. Details of the chemical pretreatment procedure are described in Wang et al. (2014). Following these pretreatments, samples were separated into a clay fraction $(<4 \mu \mathrm{m})$, fine silt fraction $(4-16 \mu \mathrm{m})$, and coarse silt fraction $(16-63 \mu \mathrm{m})$ using a

Table 1 Table caption

\begin{tabular}{|c|c|c|c|c|c|}
\hline \multirow{2}{*}{$\begin{array}{l}\text { Lab } \\
\text { code }\end{array}$} & \multirow{2}{*}{$\begin{array}{l}\text { Depth } \\
(\mathrm{cm}) \\
\text { MD06- } \\
3039\end{array}$} & \multirow{2}{*}{$\begin{array}{l}\text { Depth } \\
\text { (cm) } \\
\text { MD06- } \\
3040\end{array}$} & \multirow{2}{*}{$\begin{array}{l}\text { Conventional } \\
{ }^{14} \mathrm{C} \text { age } \\
\text { (yr BP) }\end{array}$} & \multicolumn{2}{|c|}{ Calibrated age (Marine13) } \\
\hline & & & & Intercept & Range \\
\hline & & $61-62$ & $580 \pm 20$ & 220 & $148-271$ \\
\hline GZ819 & $140-141$ & $(154-155)$ & $627 \pm 21$ & 275 & $255-293$ \\
\hline \multirow[t]{3}{*}{ GZ820 } & $210-211$ & $(231-232)$ & $1217 \pm 22$ & 752 & $716-783$ \\
\hline & & $298-299$ & $1765 \pm 30$ & 1309 & $1277-1338$ \\
\hline & & $509-510$ & $3490 \pm 25$ & 3375 & $3339-3410$ \\
\hline GZ825 & & $723-724$ & $3917 \pm 25$ & 3896 & $3850-3940$ \\
\hline GZ2018 & & $1151-1152$ & $4992 \pm 34$ & 5351 & $5294-5396$ \\
\hline \multirow[t]{2}{*}{ GZ2019 } & & $1363-1364$ & $5788 \pm 41$ & 6211 & $6179-6262$ \\
\hline & & $1457-1458$ & $6120 \pm 23$ & 6551 & $6505-6600$ \\
\hline GZ2022 & & $1611-1612$ & $7205 \pm 36$ & 7666 & $7616-7704$ \\
\hline GZ826 & & $1912-1913$ & $9479 \pm 33$ & 10324 & $10251-10369$ \\
\hline
\end{tabular}


settling method based on Stokes law; the latter two fractions were used in this study.

Prior to the ESR signal intensity measurements, $2 \mathrm{~g}$ of pretreated samples was irradiated with $\gamma$-radiation (a total dose of $2.5 \mathrm{kGy}$ ) using a ${ }^{60} \mathrm{Co}$ source at the Takasaki Advanced Radiation Research Institute, National Institutes for Quantum and Radiological Science and Technology, Takasaki, Japan, following the method of Toyoda and Hattori (2000). After irradiation, approximately $1 \mathrm{~g}$ of pretreated samples was heated at $300{ }^{\circ} \mathrm{C}$ for $15 \mathrm{~min}$ to convert the oxygen vacancies of quartz to $\mathrm{E}_{1}{ }^{\prime}$ centers (Toyoda and Ikeda 1991). The ESR signal intensity measurements were conducted using a JEOL JESFA100ESR spectrometer at the University of Tokyo at room temperature under $0.01 \mathrm{~mW}$ of microwave power, $0.1 \mathrm{mT}$ of magnetic field modulation $(100 \mathrm{kHz}), 5 \mathrm{mT}$ of scan range, 2 min of scan time, and a time constant of $0.03 \mathrm{~s}$ (Wang et al. 2014). The reproducibility of the ESR signal intensity was \pm 1.0 spin unit.

\section{X-ray powder diffraction analysis}

The CI of quartz was originally defined by Murata and Norman (1976) on the basis of the degree of resolution of the d (212) reflection of quartz at $1.3820 \AA$ on the Xray diffraction (XRD) profile. The CI of quartz reflects physical conditions during quartz formation and is typically the highest for quartz formed under high temperatures and/or formed at a slow crystallization rate. In this study, measurement of the CI of quartz was conducted using a PANalytical X'Pert PRO X-ray diffractometer at the University of Tokyo with a $\mathrm{CuK}_{\alpha}$ beam generated at a voltage of $45 \mathrm{kV}$ and a current of $40 \mathrm{~mA}$ with a divergence slit $1.52 \mathrm{~mm}$ in width and an anti-scatter slit 3 $\mathrm{mm}$ in width. The CI values were calculated as the degree of the quartz peak split at $67.74^{\circ} 2 \theta$, based on the definition of Murata and Norman (1976). The CI of quartz was also used to constrain the provenance of quartz. The reproducibility of the CI for five repeated XRD measurements was \pm 0.25 .

The quartz content (QC) was determined using the internal standard method (Klug and Alexander 1974) with silicon (Wako Co., Ltd.) as an internal standard. Measurement for QC was also conducted using the PANalytical X'Pert PRO X-ray diffractometer at the University of Tokyo with a $\mathrm{CuK}_{\alpha}$ beam generated at a voltage of 45 $\mathrm{kV}$ and a current of $40 \mathrm{~mA}$ with a divergence slit1.52 $\mathrm{mm}$ in width and an anti-scatter slit $3 \mathrm{~mm}$ in width. The QC was calculated by the ratio of the quartz peak height at $20.9^{\circ} 2 \theta$ and silicon peak height at $27.9^{\circ} 2 \theta$ measured on the XRD profile; the peak height ratio between the quartz and silicon was translated to the $\mathrm{QC}$ in weight percent using a predetermined calibration equation. The quartz peak height was corrected for the effect of crystallinity based on the method of Isozaki (2009). The reproducibility of the QC was $\pm 3 \%$.

According to our previous study, the fine silt fraction $(4-16 \mu \mathrm{m})$ of the detrital sediment is considered as mainly representing SPM (Saito et al. 2017) whereas the coarse silt fraction $(16-63 \mu \mathrm{m})$ represents suspension particles under high water discharge and/or saltation particles transported by bottom currents (Wang et al. 2011). The grain size distribution of the MD06-3040 core sediments showed a modal size of the major grain size population at $4-8 \mu \mathrm{m}$ and modal sizes of minor grain size populations at $0.8-4 \mu \mathrm{m}$ and $16-22 \mu \mathrm{m}$ (Fig. 2). The fine silt fraction $(4-16 \mu \mathrm{m})$ of the MD06-3040 core sediments, and its proportion during the period $6-0 \mathrm{kyr}$ $\mathrm{BP}$, is $64.5 \%$ on average except for the coarse silt to sandy sediment at a depth interval of $2.7-2.9 \mathrm{~m}$ (1.11.2 kyr BP), enabling representation of the SPM from the Yangtze River. Therefore, our provenance study mainly focuses on quartz in the fine silt fraction (4$16 \mu \mathrm{m})$.

\section{Results}

Temporal changes in the ESR signal intensity of quartz in the fine silt fraction $(4-16 \mu \mathrm{m})$ and coarse silt fractions $(16-63 \mu \mathrm{m})$

The red curve in Fig. 3a shows the temporal changes in the ESR signal intensity of quartz in the fine silt fraction $(4-16 \mu \mathrm{m})$ of the MD06-3040 core samples during the last 10 kyrs, which ranges between 3.5 and 24.0 with an average of 8.9 and a standard deviation of 3.2. From 10 to $6.0 \mathrm{kyr} \mathrm{BP}$, the ESR signal intensity is high and highly variable, ranging between 3.8 and 23.7 with an average of 12.3 and a large standard deviation of 5.0. From 6.0 to $4.1 \mathrm{kyr}$ BP, the ESR signal intensity remains relatively high ranging from 7.3 to 24.0 with an average of 10.8 and a moderate standard deviation of 3.2. During this interval, the ESR signal intensity rapidly decreased to 7.3 at $5.8 \mathrm{kyr} \mathrm{BP}$, then gradually increases to ca. 15 at $4.5 \mathrm{kyr} \mathrm{BP}$, and then decreased again to 4.6 at $4.1 \mathrm{kyr}$ BP. From 4.1 to $3.5 \mathrm{kyr}$ BP, the ESR signal intensity slightly increases and remains relatively low between 4.6 and 12.1 with an average of 7.9 and a small standard deviation of 1.9. From 3.5 to $2.0 \mathrm{kyr}$ BP, the ESR signal intensity is low, ranging from 3.5 to 12.6 with an average of 6.0 and a small standard deviation of 1.9. The ESR signal intensity rapidly decreases to 4.1 at $3.5 \mathrm{kyr} \mathrm{BP}$ and then gradually increases to 5.6 at $2.0 \mathrm{kyr}$ BP. From $2.0 \mathrm{kyr}$ BP to the present, the ESR signal intensity slightly increases, ranging from 12.1 to 5.4 with an average of 8.4 and a small standard deviation of 1.6. It shows a higher value of 9.8 at $1.5 \mathrm{kyr} \mathrm{BP}$ and lower values of less than 6.0 at 0.6 and $0.3 \mathrm{kyr}$ BP.

The blue curve in Fig. 3a shows temporal changes in the ESR signal intensity in the coarse silt fraction (16- 

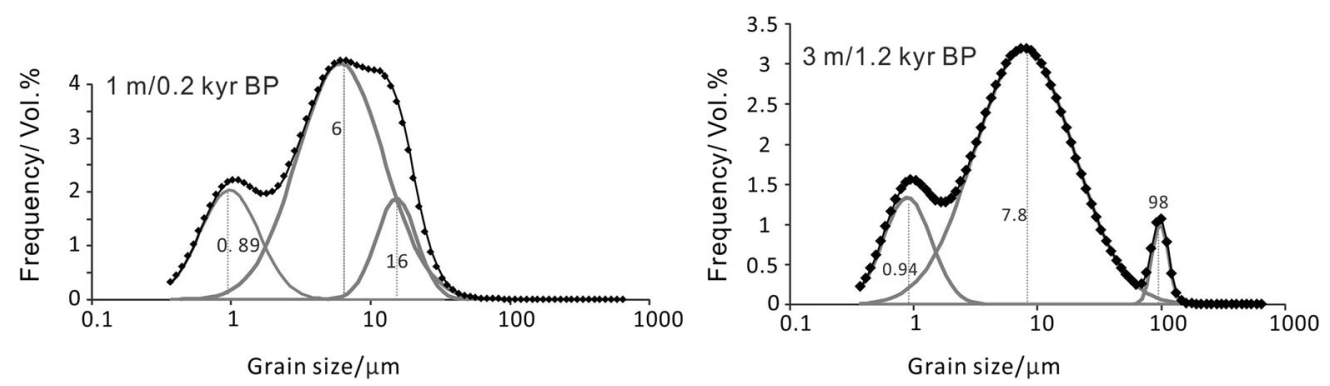

Fig. 2 Typical grain size distributions of the MD06-3040 core sediments at a depth interval of $1 \mathrm{~m}$ (0.2 kyr BP) and 3 m (1.2 kyr BP)

$63 \mu \mathrm{m}$ ) during the last $10 \mathrm{kyrs}$, which varies between 3.0 and 13.4 with an average of 6.8 and a standard deviation of 2.1. From 10 to 6.0 kyr BP, the ESR signal intensity is more or less constant ranging from 5.9 to 10.2 with an average of 7.4 and a small standard deviation of 1.5 . From 6.0 to 4.1 kyr BP, the ESR signal intensity ranges from 3.0 to 10.0 with an average of 5.8 and a standard deviation of 1.8. During this interval, the ESR signal intensity continues to be constant until $4.4 \mathrm{kyr}$ BP. From 4.1 to $3.5 \mathrm{kyr} \mathrm{BP}$, the ESR signal intensity ranges from 3.3 to 9.8 with an average of 7.0 and a standard deviation of 1.6. During this interval, it rapidly decreases to 3.3 at

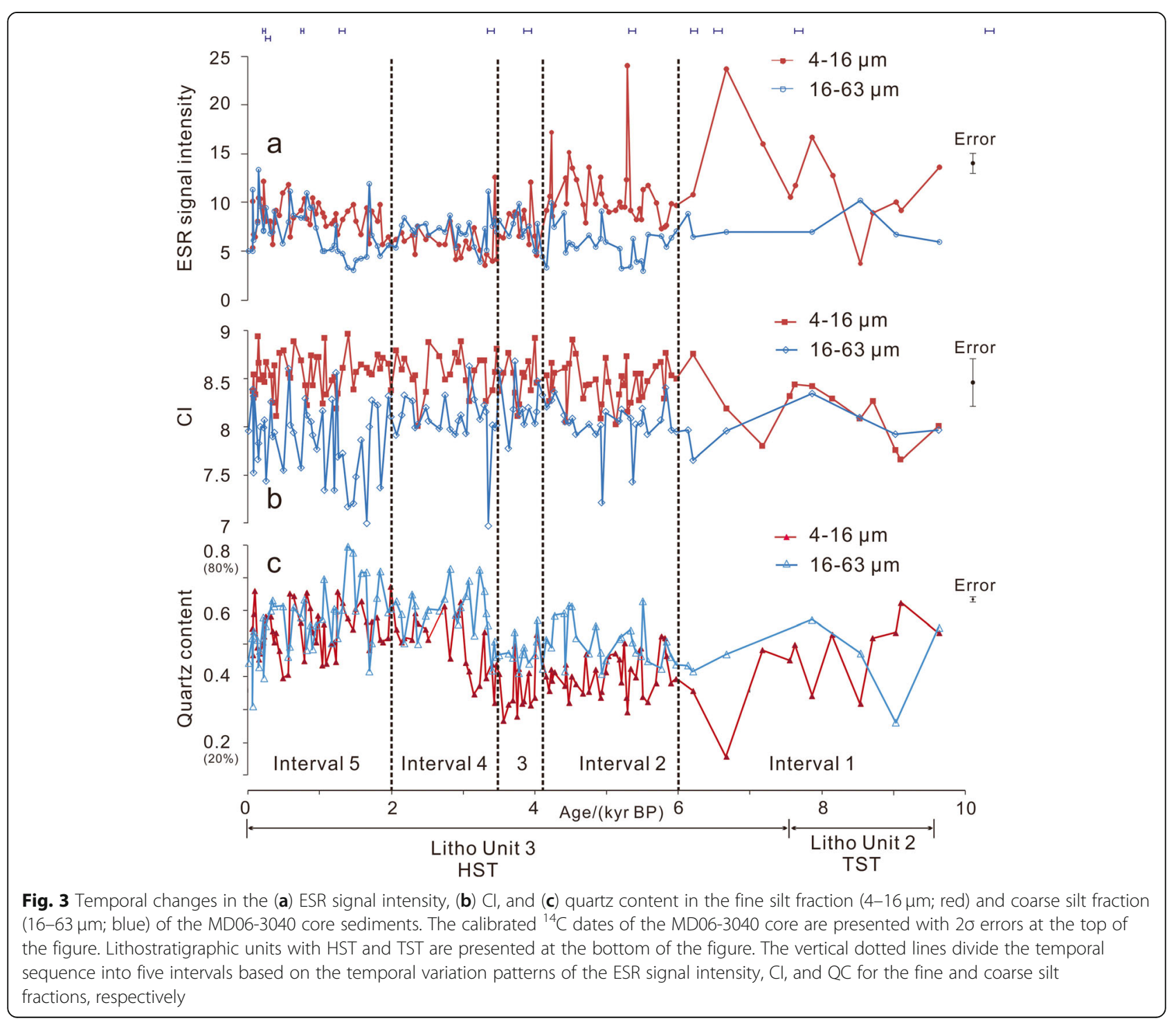


$4.1 \mathrm{kyr}$ BP and then gradually increases to 8.1 at $3.5 \mathrm{kyr}$ BP. From 3.5 to $2.0 \mathrm{kyr}$ BP, the ESR signal intensity ranges from 3.9 to 11.2 with an average of 6.1 and a small standard deviation of 1.5. During this interval, it rapidly decreases to 5.0 at $3.3 \mathrm{kyr} \mathrm{BP}$ and remains stable at approximately 7.0 until $2.0 \mathrm{kyr}$ BP. From 1.5 to $0 \mathrm{kyr}$ $\mathrm{BP}$, the ESR signal intensity ranges from 3.1 to 13.4 with an average of 7.3 and a standard deviation of 2.5 , decreases to its lowest value of 3.1 at $1.5 \mathrm{kyr} \mathrm{BP}$, and then gradually increases to 13.4 at $0.15 \mathrm{kyr}$ BP.

When the ESR signal intensity in the fine silt and coarse silt fractions are compared, the former is higher and more variable than that of the latter from 10 to $4.1 \mathrm{kyr}$ BP, while both are similar from 4.1 to $2.0 \mathrm{kyr}$ BP. The ESR signal intensity in the fine silt fraction becomes higher than that in the coarse silt fraction again from 1.8 to $0.9 \mathrm{kyr} \mathrm{BP}$, while both are similar again beginning at 0.9 kyr BP.

\section{Temporal changes in the $\mathrm{Cl}$ in the fine silt fraction (4- $16 \mu \mathrm{m})$ and coarse silt fractions (16-63 $\mu \mathrm{m})$}

The red curve in Fig. $3 \mathrm{~b}$ shows the temporal changes in the CI of quartz in the fine silt fraction $(4-16 \mu \mathrm{m})$ of the MD06-3040 core samples during the last 10 kyrs. During this interval, it varies between 7.7 and 9.0 with an average of 8.5 and a standard deviation of 0.3 . From 10 to $6.0 \mathrm{kyr} \mathrm{BP}$, the CI of quartz in the fine silt fraction is more or less constant between 7.7 and 8.8 with an average of 8.2 and a standard deviation of 0.3 . It slightly increases, but remains more or less constant, between 8.0 and 9.0 with an average of 8.5 and a smaller standard deviation of 0.2 from 6.0 to $0 \mathrm{kyr} \mathrm{BP}$.

The blue curve in Fig. 3b shows the CI of quartz in the coarse silt fraction $(16-63 \mu \mathrm{m})$ that ranges between 7.0 and 8.7 with an average of 8.0 and a standard deviation of 0.32 during the last 10 kyrs. The $\mathrm{CI}$ of quartz in the coarse silt fraction is more or less constant between 8.3 and 7.7 with an average of 8.0 and a standard deviation of 0.2 from 10 to $6.0 \mathrm{kyr} \mathrm{BP}$ and ranges between 7.0 and 8.7 with an average of 8.1 and a standard deviation of 0.3 from 6.0 to $2.0 \mathrm{kyr}$ BP. The CI of quartz in the coarse silt fraction ranges between 7.0 and 8.5 with an average of 7.8 and a relatively large standard deviation of 0.5 from 2.0 to $1.2 \mathrm{kyr} \mathrm{BP}$ and is relatively variable between 7.3 and 8.6 with an average of 7.9 and a standard deviation of 0.3 from 1.2 to 0 kyr BP.

The CI of quartz in the coarse silt fraction shows values similar to those in the fine silt fraction from 10 to $6.0 \mathrm{kyr}$ BP. The CI of quartz in the coarse silt fraction is greater than that in the fine silt fraction and CI of the two fractions shows an opposite variation trend from 6.0 to $0 \mathrm{kyr} \mathrm{BP}$ at a millennial time scale. Compared to the temporal changes in the ESR signal intensity of quartz, the temporal variation patterns of the $\mathrm{CI}$ of quartz in the two fractions does not show obvious changes at 4.1 and $3.5 \mathrm{kyr}$ BP. The CI of quartz in the coarse silt fraction shows a sudden decrease at $2.0 \mathrm{kyr}$ BP that lasts until 1.2 kyr BP.

When the CI of quartz in the fine silt fraction and that in the coarse silt fraction are compared, both vary from 10.0 to $6.0 \mathrm{kyr} \mathrm{BP}$; the former is relatively stable compared to the latter from $6.0 \mathrm{kyr} \mathrm{BP}$ to the present. The $\mathrm{CI}$ of quartz in the fine silt fraction maintains a higher value than that in the coarse silt fraction from 10.0 to 0 kyr BP.

\section{Temporal changes in the QC in the fine silt fraction (4-} $16 \mu \mathrm{m})$ and coarse silt fractions $(16-63 \mu \mathrm{m})$

The red curve in Fig. 3c shows the temporal changes in the QC in the fine silt fraction which varies between 0.2 and 0.6 with an average of 0.4 and a standard deviation of 0.08 with a slight decreasing trend from 10 to $3.5 \mathrm{kyr}$ BP. It suddenly increases from 0.3 at $3.5 \mathrm{kyr} \mathrm{BP}$ to 0.6 at $2.9 \mathrm{kyr} \mathrm{BP}$, and then maintains a more or less constant value between 0.4 and 0.7 with an average of 0.5 and a standard deviation of 0.1 from 3.5 to $0 \mathrm{kyr} \mathrm{BP}$.

The blue curve in Fig. 3c shows the temporal changes in the QC in the coarse silt fraction which varies between 0.3 and 0.8 with an average of 0.5 and a standard deviation of 0.1 over the last 10 kyrs. The QC in the coarse silt fraction varies between 0.3 and 0.6 with an average of 0.5 and a standard deviation of 0.1 from 10 to $6.0 \mathrm{kyr} \mathrm{BP}$, and then varies between 0.4 and 0.6 with an average of 0.5 and a standard deviation of 0.06 from 6.0 to $3.5 \mathrm{kyr} \mathrm{BP}$. The QC in the coarse silt fraction increases to 0.7 at $3.3 \mathrm{kyr} \mathrm{BP}$, and then varies between 0.1 and 0.8 with an average of 0.6 and a standard deviation of 0.1 from 3.5 to $0 \mathrm{kyr}$ BP.

The QC in both the fine silt and coarse silt fractions show similar temporal trends; the QC in the coarse silt fraction is slightly larger than that that in fine silt fraction from 10.0 to $0.6 \mathrm{kyr} \mathrm{BP}$.

\section{Recognition of each interval and relationship with the lithostratigraphic unit}

Based on the temporal variation patterns in ESR signal intensity, the $\mathrm{CI}$ and $\mathrm{QC}$ for both fine and coarse silt fractions, as previously described, were divided into the five intervals that are supposed to reflect changes in provenance. Namely, interval 1 (from 10 to $6.0 \mathrm{kyr} \mathrm{BP}$ ) is characterized by a high ESR signal intensity, moderate quartz $\mathrm{CI}$, and variable $\mathrm{QC}$ in both fractions. Following interval 1, the ESR signal intensity and QC in both fractions become moderately variable, and the $\mathrm{CI}$ of quartz in the fine silt fraction remains constant. Interval 2 (from 6.0 to $4.1 \mathrm{kyr} \mathrm{BP}$ ) is characterized by a relatively high and moderately variable ESR signal intensity of 
quartz and a moderate $\mathrm{CI}$ and low $\mathrm{QC}$ in both fractions. Interval 3 (from 4.1 to $3.5 \mathrm{kyr} \mathrm{BP}$ ) is characterized by a similar, moderately variable ESR signal intensity of quartz and a moderate $\mathrm{CI}$ and low QC in both fractions. Interval 4 (from 3.5 to $2.0 \mathrm{kyr} \mathrm{BP}$ ) is characterized by a similar low ESR signal intensity of quartz with low variability, a moderate and variable $\mathrm{CI}$, and an increasingly high QC with high variability in both fractions. Interval 5 (from 2.0 to $0 \mathrm{kyr} \mathrm{BP}$ ) is characterized by a low to moderate ESR signal intensity of quartz with a low variability in the fine silt fraction, a low to moderate ESR signal intensity of quartz with high variability in the coarse silt fraction, a moderate and more or less constant $\mathrm{CI}$ in the fine silt fraction and a variable $\mathrm{CI}$ in the coarse silt fraction, and a high QC in both fractions.

The sedimentary facies and lithostratigraphic unit division of the MD06-3040 core have been reported by Wang et al. (2014). Three lithostratigraphic units were defined as follows: unit 1 (19.3-18.3 $\mathrm{m}$ depth, 10.59.6 kyr BP) consisting of dark gray, moderately sorted coarse silt interbedded with $1.5-2.0$-cm layers of coarse sand rich in bivalve shell fragments; unit 2, (18.3-15.86 $\mathrm{m}$ depth, 9.6-7.5 kyr BP), consisting of dark gray medium silt interbedded with a few thin layers of fine sand showing ripples with rare bioturbation; and unit 3 (15.86-0 m depth, 7.5 kyr BP-present), dominated by yellow to olive gray silty clay and fine silt. In brief, units 1 and 2 are interpreted as TST which represent a transition from the nearshore subtidal environment to the nearshore shelf environment with rare tidal influence in response to the postglacial sea-level rise. Unit 3 was interpreted as possibly an HST (Wang et al. 2014).

Interval 1 corresponds to lithostratigraphic unit 2 in addition to the basal part of unit 3, which is equivalent to a TST. Intervals 2 to 5 correspond to lithostratigraphic unit 3, which is composed of mud deposits characteristic of the mud belt and represents a HST, whose deposition began when the contribution of fine-grained SPM derived from the Yangtze River became significant with rare tidal influence at $6 \mathrm{kyr}$ BP (Wang et al. 2014).

\section{Discussion}

\section{Temporal changes in the provenance of fine detrital} quartz in the MD06-3040 core sediments

The EASM is characterized by a seasonal northwestward migration of its precipitation front, of which the timing and extent is controlled by migration of the WJ axis (Sampe and Xie 2010). Such migration of the main precipitation area would also have occurred at longer time scales (Tada et al. 2016). The ESR signal intensity and CI of quartz have been used to estimate the mixing ratios of the fine silt fraction of sediments from the different tributaries in the Yangtze drainage (Saito et al. 2017). Saito et al. (2017) suggested that if migration of the main precipitation area occurred within the Yangtze River drainage, it would have been manifested as changes in the provenance of SPM discharged from the Yangtze River. If correct, the centennial-to-millennialscale variations in the main position of the EASM precipitation front could have been recorded as changes in the provenance of the fine-silt-sized sediment corresponding to SPM discharged from the Yangtze River. Saito et al. (2017) subdivided the entire drainage of the Yangtze River into the upper Jinshajiang, western tributaries, northeastern tributaries, and southeastern tributaries, respectively, based on the ESR signal intensity and CI of quartz of the fine silt fraction in each tributary (Fig. 4). The result enables discrimination of the sediment contributions from the upper-middle reaches (northwestern part of the drainage) versus the lower reaches (southeastern part of the drainage) of the Yangtze River drainage.

The Yangtze River annually delivers a huge SPM load into its estuarine system and the ECS, resulting in a great impact on sedimentation in the inner shelf of the ECS, particularly in the mud belt during the Holocene (Liu et al. 2006, 2007; Zheng et al. 2010; Wang et al. 2014; Liu et al. 2014; Yang et al. 2015; Bi et al. 2017; Liu et al. 2018). Therefore, the inner shelf sediments deposited as the mud belt are the most appropriate sediments to study the provenance changes of SPM delivered via the Yangtze River.

The proportion of clay, fine silt, and coarse silt fraction in the bulk samples of the MD06-3040 core during the period $6.0-0 \mathrm{kyr}$ on average is $17.3 \%, 64.5 \%$, and $18.1 \%$, respectively. The geochemical compositions and clay mineral assemblages of MD06-3040 core sediments suggests that most of the terrigenous sediments originated from the Yangtze River (Zheng et al. 2010; Yang et al. 2015; Bi et al. 2017), with minor contribution from Taiwan island during the entire Holocene (Fang et al. 2018). However, sediments deposited at the MD06-3040 site during the period from 7.5 to $6 \mathrm{kyr}$ BP occasionally show quasi-bimodal grain size distributions, which is similar to that of typical modern sediments from the inner margin of the mud belt (Liu et al. 2006). This quasi-bimodal grain size distribution of MD06-3040 core sediments can be explained by occasional contribution of coarse silt to sand sediments supplied from local rivers such as the Qiantang, Min, and Ou rivers. The ESR signal intensity and the $\mathrm{CI}$ of quartz in the coarse silt fraction $(16-63 \mu \mathrm{m})$ of the MD06-3040 core sediments also suggest potential contributions from these local rivers (Wang et al. 2014). Because the MD06-3040 core, in which fine silt is the relatively dominant faction derived from the Yangtze River with lesser impacts from local rivers and Taiwan island, is the longest continuous piston core collected from the central mud belt 


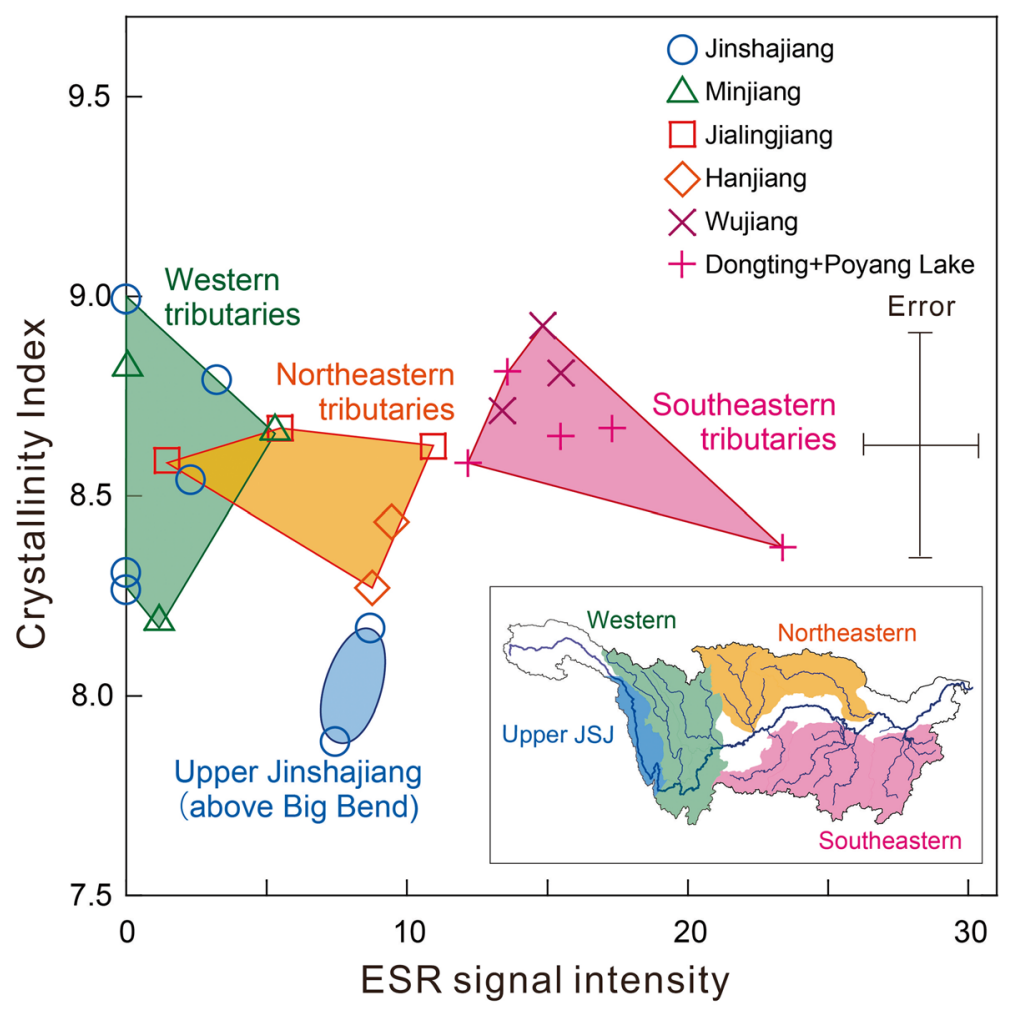

Fig. 4 ESR signal intensity vs. Cl plot of quartz in the fine silt fraction of the riverbed samples from the major tributaries of the Yangtze River from Saito et al. (2017)

representing extensive sediment succession thus far, we examined the provenance changes in the fine silt fraction of the MD06-3040 core sediments to reconstruct spatiotemporal variability in the EASM precipitation area (EASM front) within the Yangtze River drainage.

Figure 5 shows a comparison of the ESR signal intensity and CI of quartz in the fine silt fraction of MD063040 core sediments in intervals 2 to 5 to those of the four major source areas in the modern Yangtze River drainage shown in Fig. 4. On the ESR signal intensity versus CI diagram, most of the fine silt fraction samples from the MD06-3040 core plotted within the area of the fine silt fraction of riverbed sediments from the entire Yangtze River drainage, suggesting that they can be explained by mixing of the sediments from the four major source areas in the modern Yangtze River drainage classified by Saito et al. (2017). Notably, this result is consistent with the idea that the Yangtze River has been a predominant source of fine-silt-sized sediments on the inner shelf of ECS over the last 6 kyrs (Zheng et al. 2010; Wang et al. 2014; Yang et al. 2015; Fang et al. 2018).

Regarding provenance changes, most of the samples from interval 2 (from 6.0 to $4.1 \mathrm{yr}$ BP, Fig. 5a) are plotted within or in between the areas of the southeastern tributaries, northeastern tributaries, and upper Jinshajiang
(Fig. 5a), within an ESR signal intensity range of 7-24 and CI range of 8.0-8.9. The exception is one sample characterized by a relatively high ESR signal intensity and low CI, which possibly originated from local sources such as the Qintang and Ou rivers (Wang et al. 2014). Thus, we infer that the quartz in the fine silt fraction $(4-16 \mu \mathrm{m})$ of the sediments deposited during this interval is a mixture of quartz derived from the southeastern and northeastern tributaries of the Yangtze River and the upper Jinshajiang with a possible rare contribution from the Qiantang and/or Ou rivers. Fang et al. (2018) examined the clay mineralogy of the MD06-3040 core and tentatively concluded that kaolinite content (\%) represented the contribution of the Fujian-derived source, illite content (\%) was a contribution from the Taiwanese source, and the contribution from the Yangtze River was the sum of its smectite proportion (\%) and illite content (\%). They also suggested that most fine-grained $(<2 \mu \mathrm{m})$ terrigenous sediments originated from the Yangtze River, with a minor contribution from Taiwan island and the nearby Zhejiang and Fujian provinces during the entire Holocene (Fang et al. 2018). However, using clay mineral analyses of sediments from the MZ02 core retrieved from the mud belt area of the inner ECS, Liu et al. (2014) suggested that the increased strength of the TWC might have played an important role in sediment 

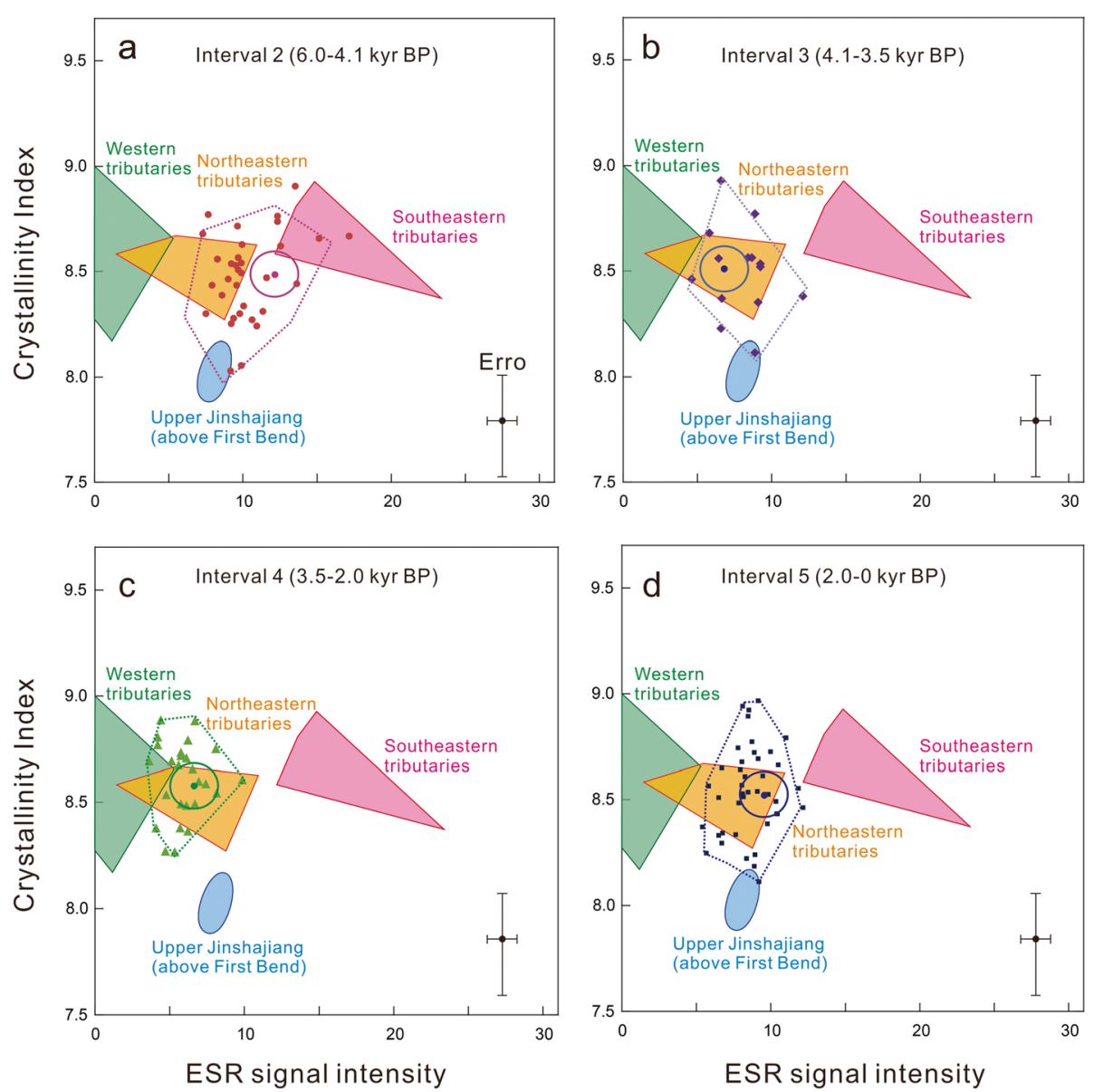

Fig. 5. a-d Comparison of the ESR signal intensity and $\mathrm{Cl}$ of quartz in the fine silt fraction of MD06-3040 core sediments to those sediments from various parts of the modern Yangtze River drainage (Saito et al. 2017) for intervals 2 to 5 covering the last 6.0 kyr BP identified in this study. The circles represent the average values of the ESR signal intensity and $\mathrm{Cl}$ of quartz during each individual interval

dispersal and deposition on the inner shelf of the ECS during the period 6.2-2.4 kyr BP, with a dominance of greater than $60 \%$ of the sediments transported from Taiwanese rivers (Liu et al. 2014). However, our result suggested that the fine silt faction was derived from the southeastern and northeastern tributaries of the Yangtze River and the upper Jinshajiang with a possible rare contribution from the local Qiantang and/or Ou rivers during the period 6.0-4.2 kyr BP. We insist that different grain sizes might show different results despite the same original source due to hydrodynamic sorting and preferential mineral alteration (Clift et al. 2015). The previous provenance studies focused on the clay-sized $(<2 \mu \mathrm{m})$ fraction; we used the fine silt fraction $(4-16 \mu \mathrm{m})$ which is the predominate fraction of SPM discharged from the Yangtze River and deposited at the MD06-3040 site.

The fine silt fractions of samples from interval 3 (from 4.1 to $3.5 \mathrm{kyr}$ BP, Fig. 5b) fall mainly within the area of the northeastern tributaries with a relatively narrow ESR signal intensity range of 4-10 and CI range of 8.1-8.9. We interpret that the quartz in the fine silt fraction of the sediments deposited during this interval is mostly derived from the northeastern tributaries of the Yangtze River.

Most of samples from interval 4 (from 3.5 to $2.0 \mathrm{kyr}$ BP, Fig. 5c) fall within the areas of the western and northeastern tributaries within an ESR signal intensity range of 5-13 and CI range of 7.8-8.8. The exceptions are two samples, one at $2.4 \mathrm{kyr} \mathrm{BP}$ and the other at 3.4 kyr BP, which fall near the southeastern tributaries. Thus, we interpret that the quartz in the fine silt fraction of the sediments deposited during this interval is mainly derived from the western and northeastern tributaries of the Yangtze River.

Most of samples from interval 5 (from 2.0 to $0 \mathrm{kyr}$ BP, Fig. 5d) fall within the area of the northeastern tributaries within am ESR signal intensity range of 5-14 and a CI range of 8.2-9.0. Some samples fall within the area of the upper Jinshajiang, suggesting potential contribution from this area. We interpret that the quartz in the fine silt fraction of the sediments deposited during this 
interval is mainly derived from the northeastern tributaries of the Yangtze River with a contribution from the upper Jinshajiang.

Hydrological data of a past 30-year time scale (19501980) were collected from the upper, middle, and lower Yangtze River (Chen et al. 2001) to examine the temporal and spatial distribution of discharge and sediment load in the Yangtze drainage. Sediment load in the upper and middle Yangtze had been decreasing along with the decreasing water discharge, which is possibly due to water diversion for intensive agriculture (Chen et al. 2001). Gao et al. (2019) analyzed the siltation and erosion state of the estuary-shelf depositional systems by combining the spatial distribution of deposition rates, types of vertical distribution profiles of ${ }^{210} \mathrm{~Pb}$ activity, and distribution of grain size composition in surficial sediments and discussed the response intensity and timing of the depositional system in the Yangtze subaqueous delta and mud belt area. Their results showed that the abrupt reduction in the sediment discharge to the estuary disturbed the equilibrium among the estuarine, coastal, and shelf depositional systems following operation of the Three Gorges Dam in 2003, modifying the siltation-erosion balance and seabed sediment types (Gao et al. 2019). Regarding the Yangtze River-ECS source-to-sink system, human impact during the late Holocene, particularly recent decades, is of considerable importance.

\section{Changes in the heavy precipitation area within the Yangtze River drainage during the last 6 kyrs}

As mentioned in the introduction, SPM constitutes greater than $95 \%$ of the sediment load discharged from the Yangtze River (Chen et al. 2001), and a strong positive relationship $\left(R^{2}=0.81\right)$ exists between the sediment load and fresh water discharge (Xu et al. 2010), while fresh water discharge of the Yangtze River could reflect precipitation amounts in the drainage (Chen et al. 2014). Thus, discharge of SPM from the Yangtze River should reflect precipitation amounts in the drainage. Based on this, we hypothesized that changes in the SPM provenance reflect changes in the distribution of highprecipitation areas. Based on temporal changes in the ESR signal intensity in the MD06-3040 core, we interpret that the ESR signal intensity increase during the period 6.0-4.1 kyr BP suggests retreat of the EASM precipitation front southeast in the Yangtze drainage (a weak EASM). In contrast, the ESR signal intensity decrease during the period 3.5-2.0 kyr BP suggests penetration of the EASM precipitation front northwestward (an enhanced EASM). The slight increase in the ESR signal intensity during the period 2.0-0 kyr BP suggests retreat of the EASM precipitation front toward the southeast in the Yangtze drainage again.
EASM precipitation variability during the Holocene has been discussed based on various reconstructions using a variety of proxies. For example, Nagashima et al. (2013) reported the relationship between spatial variations in EASM precipitation and the westerly jet (WJ) path over East Asia during the Holocene using the provenance of eolian dust in the Japan Sea sediment core DGC-6 via ESR signal intensity and CI of quartz. The variation pattern of the eolian dust provenance manifested as changes in the ESR signal intensity of the quartz in the Japan Sea sediment core D-GC-6 (Fig. 6b) is similar to that of our ESR signal intensity changes in the MD063040 core (Fig. 6a). Namely, migration of the WJ southward during the period 6.0-3.5 kyr BP and northwestward during the period 3.5-2.0 kyr BP inferred from changes in the eolian dust provenance in the sediments of the Japan Sea correlated well with our results of EASM precipitation front movement with the retreat of the EASM precipitation front southeastward during the period 6.0-4.1 kyr BP as well as the deepest northwestward penetration during the period 3.5-2.0 kyr BP (an enhanced EASM). This agreement argues for coupling between the WJ and EASM precipitation front at a millennial time scale.

Kubota et al. $(2010,2015)$ reported changes in $\delta^{18} \mathrm{O}_{s w}$, an indirect indicator of SSS, calculated from the $\mathrm{Mg} / \mathrm{Ca}$ and $\delta^{18} \mathrm{O}$ of the planktonic foraminifera Globigerinoides ruber in KY07-04-01 core sediments retrieved from the northern end of the ECS, which they interpreted as reflecting changes in the summer SSS due to changes in fresh water discharge from the Yangtze River that reflected changes in EASM precipitation in South China during the Holocene. Their higher $\delta^{18} \mathrm{O}_{\mathrm{sw}}$ peaks representing the lower Yangtze River discharge events at 6.1, $5.13 .5,2.1$, and $0.8 \mathrm{kyr}$ BP seem to correspond to our ESR signal intensity minima of the MD06-3040 core at 5.8, 5.1, 3.5, 2.0, and $0.6 \mathrm{kyr}$ BP (Fig. 6c), suggesting more contribution from the northwestern area of the Yangtze drainage during these events. This idea is further supported by stalagmite $\delta^{18} \mathrm{O}_{\mathrm{c}}$ values that show positive peaks during these periods suggesting lower EASM precipitation in South China (Dykoski et al. 2005; Hu et al. 2008, Fig. 6d, e). Furthermore, EASM precipitation front movement in the Yangtze River drainage was inferred from the ESR signal intensity of quartz in the fine silt faction of the MD063040 core sediments, and water discharge from the Yangtze River reconstructed by Kubota et al. (2015) synchronously changed at multi-centennial scale during the periods 6-5.1, 5.1-4.1, 4.1-3.5, 3.5-2.1, and 2.1-0.8 kyr BP (Fig. 6c). This observation implies that northwestward penetration of the EASM front (the increase in contribution from the northwestern area of the Yangtze drainage) at a multi-centennial time scale may have caused a significant decrease in local summer precipitation and water 


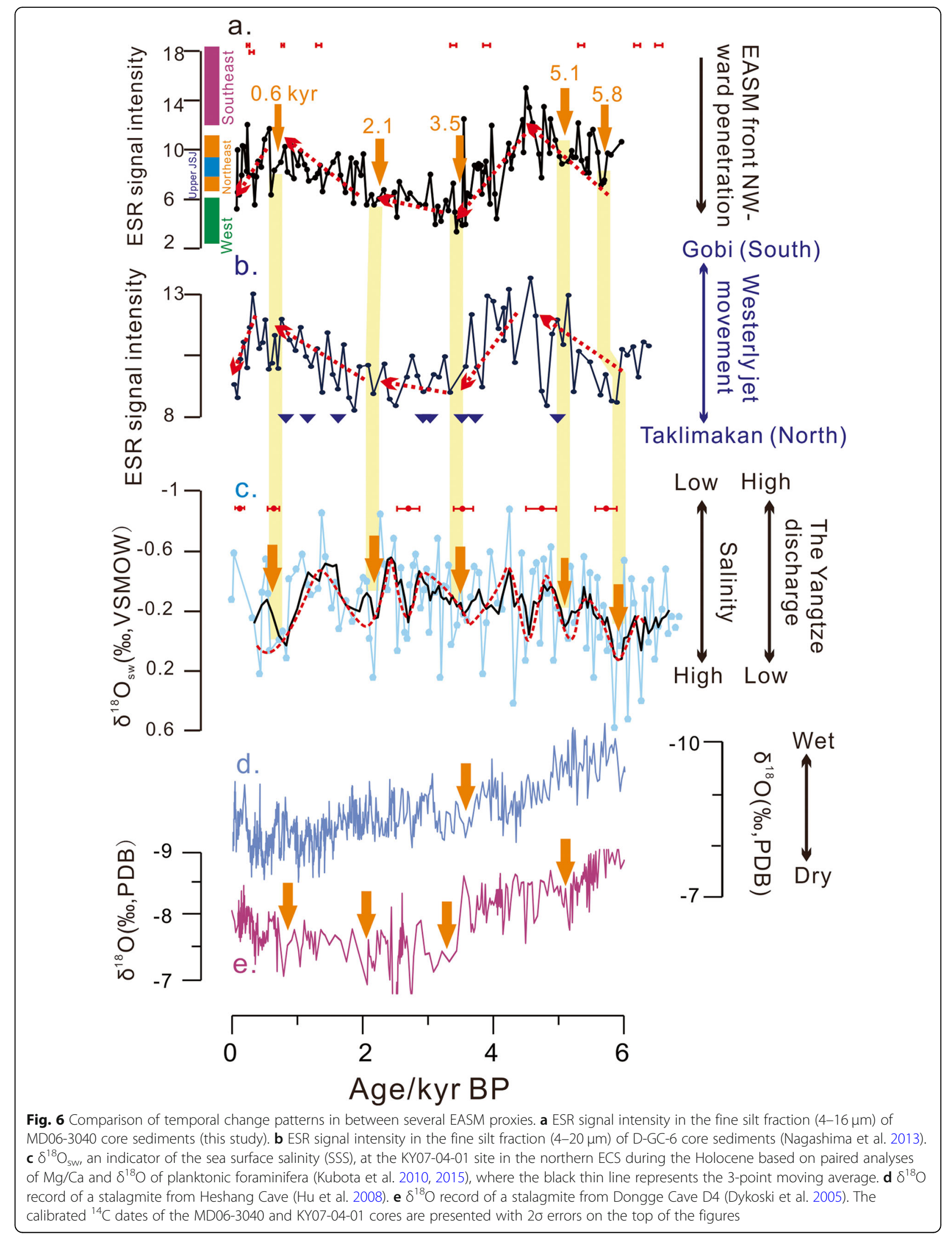


discharge from the southeastern Yangtze River drainage that exceeded the increase in the water discharge from the northwestern Yangtze River drainage.

Based on geological evidence including lake levels, pollen assemblages, and magnetic susceptibility of a loesspaleosol sequence together with numerical modeling results, An et al. (2000) summarized the spatiotemporal distribution of summer monsoon precipitation during the Holocene and proposed an "asynchronous Holocene optimum" hypothesis assuming a stepwise latitudinal shift of the maximum precipitation from northwestern China during the early Holocene to southeastern China during the late Holocene in response to progressively decreased summer insolation. This interpretation is different from our results of the ESR signal intensity of the MD06-3040 core, suggesting higher summer precipitation in the southeastern part of the Yangtze River drainage during the period 6.0-4.1 kyr BP. Previous studies may have been unable to obtain similar results because they were subject to uncertainties in the age model, an asynchronous response pattern from a number of different proxies and poor spatial coverage, particularly in the broad Yangtze drainage.

However, our ESR signal intensity results from the MD06-3040 core suggest that southeastward retreat of the precipitation front (a weaker EASM) and higher summer precipitation in the southeastern Yangtze River drainage during the period 6.0-4.1 kyr BP is attributable to weaker EASM convection (Zhou et al. 2009) rather than enhanced EASM intensity as advocated by previous works. Based on numerical meta-analysis of 92 proxy records (72 sites) of moisture and/or temperature changes in monsoonal central Asia, the maximum moisture levels in southeastern China occurred with a southeast-northwest moisture gradient during the period 6-4 kyr BP (Wang et al. 2010). High pollen percentages of evergreen Quercus and Castanopsis as well as extremely low percentages of coniferous taxa suggested extensive growth of warm-temperate evergreen broadleaf forests supporting the prevalence of a wet climate in southeastern China during the middle Holocene (Zhao et al. 2017). Sedimentological and geochemical results of the core recovered from the Hangbu delta plain of Chaohu Lake in the lower reaches of the Yangtze drainage suggested a lake expansion from 7.4 to $4.3 \mathrm{kyr}$ BP (Shi 2006). These previous studies are consistent with our interpretation that southeastward retreat of the precipitation front (a weaker EASM) and higher summer precipitation in the southeastern Yangtze River drainage occurred during the period 6.0-4.1 kyr BP. Lake shrinkage occurred with a cold and dry sub-stage in the lower reaches of the Yangtze River drainage during the period 4.3-2.7 kyr BP (Shi 2006), while flood events in the upper reach of the Hanjiang River occurred during the periods $4.3-3.8$ and
3.6-3.0 kyr BP (Tan et al. 2018), and frequent abrupt flood events occurred in the upper Yangtze drainage during the period 4.0-3.6 kyr BP (Jia et al. 2017). These results are also consistent with our interpretation of northwestward penetration of the EASM precipitation front during the period 4.1-2.0 kyr BP.

\section{Conclusion}

We examined temporal changes in the provenance of detrital quartz in the fine silt fraction of sediments from the MD06-3040 core retrieved from the mud belt on the inner shelf of the ECS, which are considered as representing the SPM derived from the Yangtze River. We used the ESR signal intensity and CI of quartz in the fine silt fraction as provenance tracers to monitor shifts in the main location of EASM precipitation (EASM front) within the Yangtze River drainage. Our results suggest northwest-southeast oscillations of the EASM precipitation front with the deepest northwestward penetration (an enhanced EASM) during the period 3.5-2.0 kyr BP and a southeastward retreat (a weak EASM) during the periods 6.0-4.1 and 2.0-0 kyr BP. This interpretation does not agree with the prevailing view based on stalagmite $\delta^{18} \mathrm{O}_{\mathrm{c}}$ in southeastern China, suggesting an early Holocene EASM maximum and gradual decrease in EASM intensity thereafter (Wang et al. 2001, 2005). Higher summer precipitation occurred in the southeastern Yangtze River drainage during the periods 6.0$4.1 \mathrm{kyr}$ BP and 2.0-0 kyr BP due to weaker EASM convection and consequent southeastward retreat of the precipitation front rather than an enhanced EASM intensity, which is consistent with the high precipitation and abrupt climatic events in the lower Yangtze drainage and southeastern China.

\section{Abbreviations}

CDW: Changjiang Diluted Water; Cl: Crystallinity index; EASM: East Asian summer monsoon; ECS: East China Sea; ESR: Electron spin resonance; HST: Highstand systems tract; ISM: Indian summer monsoon; JCC: Jiangsu Coastal Current; KC: Kuroshio Current; MFS: Maximum flooding surface; QC: Quartz content; SPM: Suspended particulate matter; TS: Transgressive surface; TST: Transgressive systems tract; TWC: Taiwan Warm Current; WJ: Westerly jet; XRD: X-ray diffraction; YS: Yellow Sea; YSWC: Yellow Sea Warm Current; ZFCC: Zhejiang-Fujian Coastal Current

\section{Acknowledgements}

The authors sincerely thank all crews of MD155-Marco Polo II IMAGES XIV cruise on board for retrieving MD06-3040 core, researchers and staffs at the University of Tokyo, Tongji University, Institute of Geochemistry in Guangzhou, Chinese Academy of Sciences (CAS), and Peking University for laboratory assistance. We also would like to express our gratitude to Prof. Hodaka Kawahata, Mr. Hiroto Kajita from the University of Tokyo for cooperatively establishing the age model, as well as Prof. Shouye Yang from Tongji University, Prof. Masanobu Yamamoto from Hokkaido University, PEPS editor Dr. Ken Ikehara, Dr. Kana Nagashima from Japan Agency for Marine-Earth Science and Technology, Dr. Yoshimi Kubota from National Museum of Nature and Science, and two reviewers for constructive comments and suggestions greatly improving this manuscript. 


\section{Authors' contributions}

RT proposed the topic and conceived and designed the study. KW carried out the experiment, analyzed the data, and wrote the manuscript. HZ, TI, BZ, and KS collaborated with the corresponding author in the development of the manuscript. All authors read and approved the final manuscript.

\section{Funding}

This study was supported by the Japan Society for the Promotion of Science (JSPS) KAKENHI Grant Number 23221002 to Ryuji Tada, jointly supported by the Second Tibetan Plateau Scientific Expedition and Research (STEP) (2019QZKK0704), the Strategic Priority Research Program of Chinese Academy of Sciences (XDB26020301), and National Natural Science Foundation of China (NSFC) (U1902208, 41991323) to Hongbo Zheng, by the NSFC (41977378) to Bin Zhou, and by the JSPS grants JPMXS05R2900001 and 19H05595 to Masanobu Yamamoto.

\section{Availability of data and materials}

Available data are attached as Table 1. Please contact the corresponding author for further data requests.

\section{Competing interests}

The authors declare that they have no competing interests.

\section{Author details}

'Department of Earth and Planetary Science, The University of Tokyo, Tokyo, Japan. ${ }^{2}$ Yunnan Key Laboratory of Earth System Science, Yunnan University, Kunming, China. ${ }^{3}$ Planetary Exploration Research Center (PEPC), Chiba Institute of Technology, Chiba, Japan. ${ }^{4}$ Faculty of Environmental Earth Science, Hokkaido University, Sapporo, Japan. ${ }^{5}$ School of Earth Sciences and Engineering, Nanjing University, Nanjing, China.

Received: 4 May 2019 Accepted: 27 December 2019 Published online: 02 February 2020

\section{References}

An ZS, Porter SC, Kutzbach JE, Wu XH, Wang SM, Liu XD, Li XQ, Zhou WJ (2000) Asynchronous Holocene optimum of the East Asian monsoon. Quat Sci Rev 19:743-762

Bi L, Yang SY, Zhao Y, Wang ZB, Dou YG, Li C, Zheng HB (2017) Provenance study of the Holocene sediments in the Changjiang (Yangtze River) estuary and inner shelf of the East China sea. Quat Int 441:147-161

Chang P, Isobe A (2003) A numerical study on the Changjiang diluted water in the Yellow and East China Seas. J Geophys Res 108(C9):3299. https://doi.org/ 10.1029/2002JC001749

Chen C, Beardsley RC, Limeburner R, Kim K (1994) Comparison of winter and summer hydrographic observations in the Yellow and East China Seas and adjacent Kuroshio during 1986. Cont Shelf Res 14(7-8):909-929

Chen FH, Xu QH, Chen JH, Birks HJB, Liu JB, Zhang SR, Jin LY, An CB, Telford RJ, Cao XY, Wang ZL, Zhang XJ, Selvaraj K, Lü HY, Li YC, Zheng Z, Wang HP, Zhou AF, Dong GH, Zhang JW, Huang XZ, Bloemendal J, Rao ZG (2015) East Asian summer monsoon precipitation variability since the last deglaciation. Sci Rep 5:11186. https://doi.org/10.1038/srep11186

Chen J, Wu XD, Finlayson BL, Webber M, Wei TY, Li MT, Chen ZY (2014) Variability and trend in the hydrology of the Yangtze River, China: annual precipitation and runoff. J Hydrol 513:403-412

Chen ZY, Li JF, Shen HT, Wang ZH (2001) Yangtze River of China: historical analysis of discharge variability and sediment flux. Geomorphology. 41:77-91. https://doi.org/10.1016/S0022-1694(02)00028-8

Cheng H, Edwards RL, Wang YJ, Kong XG, Ming YF, Gallup CD, Kelly MJ, Wang XF, Liu WG (2006) A penultimate glacial monsoon record from Hulu Cave and two-phase glacial terminations. Geology. 34:217-220

Clift PD, Harff J, Wu J, Qui Y (2015) River-dominated shelf sediments of East Asian Seas geological society special publication, p 429

Deng B, Zhang J, Wu Y (2006) Recent sediment accumulation and carbon burial in the East China Sea. Glob Biogeochem Cycles 20:GB3014. https://doi.org/10. 1029/2005GB002559

Ding YH, Chan CL (2005) The East Asian summer monsoon: an overview. Meteorog Atmos Phys 89:117-142

Dykoski CA, Edwards RL, Cheng H, Yuan DX, Cai YJ, Zhang ML, Lin YS, Oing JM, An ZS, Revenaugh J (2005) A high-resolution, absolute-dated Holocene and deglacial Asian monsoon record from Dongge Cave, China. Earth Planet Sci Lett 233:71-86. https://doi.org/10.1016/..epsl.2005.01.036

Fang J, Liu Z, Zhao Y (2018) High-resolution clay mineral assemblages in the inner shelf mud wedge of the East China Sea during the Holocene: implications for the East Asian Monsoon evolution. Sci China Earth Sci 61: 1316-1329. https://doi.org/10.1007/s11430-017-9208-1

Feigl FJ, Fowler WB, Yip KL (1974) Oxygen vacancy model for the E1 center in $\mathrm{SiO}_{2}$. Solid State Commun 14:225-229

Gao JH, Shi Y, Sheng H, Kettnerc AJ, Yang Y, Jia JJ, Wang PY, Li J, Chen YN, Zou XQ, Gao S (2019) Rapid response of the Changjiang (Yangtze) River and East China Sea source-to-sink conveying system to human induced catchment perturbations. Mar Geol 414:1-17

Hu C, Henderson GM, Huang J, Xie S, Sun Y, Johnson KR (2008) Quantification of Holocene Asian monsoon rainfall from spatially separated cave records. Earth Planet Sci Lett 266:221-232

Isozaki Y (2009) Characterization of eolian dust and its sources in the Tarim Basin and their temporal changes during Plio-Pleistocene based on the ESR signal intensity and crystallinity index of quartz. Ph. D. thesis, The University of Tokyo, Tokyo, Japan

Jia JT, Ma CM, Zhu C, Guo TH, Xu JJ, Guan HC, Zeng MX, Huang M, Zhang Q (2017) Depositional evidence of palaeofloods during 4.0-3.6 ka BP at the Jinsha site, Chengdu Plain, China. Quat Int 440:78-89

Kajita H, Kawahata H, Wang K, Zheng HB, Yang SY, Ohkouchi N, Utsunomiya M, Zhou B, Zheng B (2018) Extraordinary cold episodes during the midHolocene in the Yangtze delta: interruption of the earliest rice cultivating civilization. Quat Sci Rev 201:418-428

Klug HP, Alexander LE (1974) X-ray diffraction procedure, 2nd edn, p 966 Kubota Y, Kimoto K, Tada R, Oda H, Yokoyama Y, Matsuzaki H (2010) Variations of East Asian summer monsoon since the last deglaciation based on $\mathrm{Mg} / \mathrm{Ca}$ and oxygen isotope of planktic foraminifera in the northern East China Sea. Paleoceanography. 25:PA4205. https://doi.org/ 10.1029/2009PA001891

Kubota Y, Kimoto K, Tada R, Uchida M, Ikehara K (2019) Millennial-scale variability of East Asian summer monsoon inferred from sea surface salinity in the northern East China Sea (ECS) and its impact on the Japan Sea during Marine Isotope Stage (MIS) 3. Prog Earth Planetary Sci 6:39

Kubota Y, Tada R, Kimoto K (2015) Changes in East Asian summer monsoon precipitation during the Holocene deduced from a freshwater flux reconstruction of the Changjiang (Yangtze River) based on the oxygen isotope mass balance in the northern East China Sea. Clim Past 11:265-281

Liu JP, Li AC, Xu KH, Velozzi DM, Yang ZS, Milliman JD, DeMaster DJ (2006) Sedimentary features of the Yangtze River-derived along-shelf clinoform deposit in the East China Sea. Cont Shelf Res 26:2141-2156

Liu JP, Xu KH, Li AC, Milliman JD, Velozzi DM, Xiao SB, Yang ZS (2007) Flux and fate of Yangtze River sediment delivered to the East China Sea. Geomorphology. 85:208-224

Liu SF, Shi XF, Fang XS, Dou YG, Liu YG, Wang XC (2014) Spatial and temporal distributions of clay minerals in mud deposits on the inner shelf of the East China Sea: implications for paleoenvironmental changes in the Holocene. Quat Int 349:270-279

Liu XT, Li AC, Jiang DJ, Lu J, Huang J, Wan SM (2018) Provenance discrimination of sediments in the Zhejiang-Fujian mud belt, East China Sea: implications for the development of the mud depocenter. J Asian Earth Sci 151:1-15

Maher BA (2008) Holocene variability of the East Asian summer monsoon from Chinese cave records: a re-assessment. The Holocene 18:861-866

Maher BA, Thompson R (2012) Oxygen isotopes from Chinese caves: records not of monsoon rainfall but of circulation regime. J Quat Sci 27:615-624

Milliman JD, Meade HR (1983) World-wide delivery of sediment to the oceans. J Geol 91(1):1-21

Milliman JD, Shen H, Yang Z, Meade HR (1985) Transport and deposition of river sediment in the Changjiang estuary and adjacent continental shelf. Cont Shelf Res 4(1-2):37-45

Milliman JD, Syvitski J (1992) Geomorphic/tectonic control of sediment discharge to the ocean: the importance of small mountainous rivers. J Geol 100(5):525-544

Murata K, Norman M (1976) An index of crystallinity for quartz. Am J Sci 276: $1120-1130$

Nagashima K, Asahara Y, Fumi Y, Takeuchi F, Harada N, Toyoda S, Tada R (2012) Contribution of detrital materials from the Yukon River to the continental shelf sediments of the Bering Sea based on the electron spin resonance signal intensity and crystallinity of quartz. Deep-Sea Res II 61-64:145-154 
Nagashima K, Tada R, Tani A, Sun Y, Isozaki Y, Toyoda S, Hasegawa H (2011) Millennial-scale oscillations of the westerly jet path during the last glacial period. J Asian Earth Sci 40:1214-1220

Nagashima K, Tada R, Tani A, Toyoda S, Sun Y, Isozaki Y (2007) Contribution of aeolian dust in Japan Sea sediments estimated from ESR signal intensity and crystallinity of quartz. Geochem Geophys Geosyst 8(2):Q02Q04. https://doi. org/10.1029/2006GC001364

Nagashima K, Tada R, Toyoda S (2013) Westerly jet-East Asian summer monsoon connection during the Holocene. Geochem Geophys Geosyst 14:5041-5053. https://doi.org/10.1002/2013GC004931

Qin YS (1979) A study on sediment and mineral compositions of the sea floor of the East China Sea. Oceanic Selections 2(2):130-142

Qin YS, Zhao YY, Chen LR, Zhao SL (1987) Geology of the East China Sea. China Science Press, Beijing

Ramsey CR, Lee S (2013) Recent and planned developments of the program OXCAL report

Reimer PJ, Bard E, Bayliss A, Beck JW, Blackwell PG, Ramsey CB, Buck CE, Cheng H, Edwards RL, Friendrich M, Grootes PM, Guilderson TP, Haflidason H, Hajdas I, Hatte C, Heaton T, Hoffmann D, Hogg AG, Hughen KA, Kaiser KF, Kromer B, Manning SW, Niu M, Reimer RW, Richards DA, Scott EM, Southon JR, Staff RA, Turney CSM, Van der Plicht J (2013) IntCal13 and Marine13 radiocarbon age calibration curves 0-50,000 years cal BP. Radiocarbon 55:1869-1887

Saito K, Tada R, Zheng H, Irino T, Luo C, He M, Wang K, Suzuki Y (2017) ESR signal intensity of quartz in the fine-silt fraction of riverbed sediments from the Yangtze River: a provenance tracer for suspended particulate matter. Prog Earth Planetary Sci 4:4. https://doi.org/10.1186/s40645-017-0118-9

Sampe T, Xie SP (2010) Large-scale dynamics of the Meiyu-baiu rainband: environmental forcing by the Westerly jet. J Clim 23(1):113-134. https://doi. org/10.1175/2009jcli3128.1

Shi Y X (2006) Sedimentary and geochemical records of climate and environmental change for the Chaohu-Hangbu River Catchment in Anhui Province. Ph.D. Thesis, Guangzhou Institute of Geochemistry, Chinese Academy of Sciences, Guangzhou, China (in Chinese with English abstract)

Sun Y, Chen H, Tada R, Weiss D, Lin M, Toyoda S, Yan Y, Isozaki Y (2013) ESR signal intensity and crystallinity of quartz from Gobi and sandy deserts in East Asia: implication for tracing Asian dust provenance. Geochem Geophys Geosyst 14:2615-2627. https://doi.org/10.1002/GGGE.20162

Sun Y, Tada R, Chen J, Chen H, Toyoda S, Tani A, Isozaki Y, Nagashima K, Hasegawa H, Ji JF (2007) Distinguishing the sources of Asian dust based on electron spin resonance signal intensity and crystallinity of quartz. Atmos Environ 41:8537-8548

Tada R, Zheng H, Clift PD (2016) Evolution and variability of the Asian monsoon and its potential linkage with uplift of the Himalaya and Tibetan Plateau. Prog Earth Planetary Sci 3:4. https://doi.org/10.1186/s40645-016-0080-y

Tan LC, Cai YJ, Cheng H, Edwards LR, Gao YL, Xu H, Zhang HW, An ZS (2018) Centennial to decadal scale monsoon precipitation variations in the upper Hanjiang River region, China over the past 6650 year. Earth Planet Sci Lett 482:580-590

Toyoda S, Hattori M (2000) Formation and decay of the E1 center and of its precursor. Appl Radiat Isot 52:1351-1356

Toyoda S, Ikeda M (1991) Thermal stabilities of paramagnetic defect and impurity centers in quartz: basis for ESR dating of thermal history. Geochem J 25:437445

Toyoda S, Naruse T (2002) Eolian dust from the Asian deserts to the Japanese Island since the last glacial maximum: the basis for the ESR method, transactions. Jpn Geomorphological Union 23(5):811-820

Wang B, Lin H (2002) Rainy season of the Asian-Pacific summer monsoon. J Clim 15:386-396

Wang B, Wu RG, Lau KM (2002) Interannual variability of the Asian summer monsoon: contrasts between the Indian and the Western North Pacific-East Asian monsoons. J Clim 14:4073-4090

Wang K, Zheng H, Tada R, Irino T, Zheng Y, Saito K, Karasuda A (2014) Millennial-scale East Asian Summer monsoon variability recorded in grain size and provenance of mud belt sediments on the inner shelf of the East China Sea during mid-to late Holocene. Quat Int 349:79-89

Wang MJ, Zheng HB, Xie X, Fan DD, Yang SY, Zhao QH, Wang K (2011) A 600year flood history in the Yangtze River drainage: comparison between a subaqueous delta and historical records. Chin Sci Bull 56:188-195

Wang YB, Liu XQ, Herzschuh U (2010) Asynchronous evolution of the Indian and East Asian summer monsoon indicated by Holocene moisture patterns in monsoonal central Asia. Earth Sci Rev 103(3):135-153
Wang YJ, Cheng H, Edwards RL, He Y, Kong X, An Z, Wu J, Kelly MJ, Dykoski CA Li X (2005) The Holocene Asian monsoon: links to solar changes and North Atlantic climate. Science 308:854-857

Wang YJ, Cheng H, Edwards RL, Wu JY, Shen CC, Dorale JA (2001) A highresolution absolute-dated Late Pleistocene monsoon record from Hulu Cave, China. Science 294:2345-2348

Xu J, Yang D, Yi Y, Lei Z, Chen J, Yang W (2008) Spatial and temporal variation of runoff in the Yangtze River basin during the past 40 years. Quat Int 186:3242

Xu K, Milliman J, Xu H (2010) Temporal trend of precipitation and runoff in major Chinese Rivers since 1951. Glob Planet Chang 73(3-4):219-232

Yang SY, Wang ZB, Dou YG, Shi XF (2015) Major sinks of the Changjiang (Yangtze River)-derived sediments in the East China Sea during the late quaternary. Geol Soc Lond, Spec Publ 429:137-152

Yang ZS, Guo ZG, Wang ZX (1992) Basic pattern of transport of suspended matter from the Yellow Sea and East China Sea to the eastern deep seas. Acta Oceanol Sin 14(2):81-90 in Chinese, with English summary

Yim SY, Wang B, Liu J, Wu ZW (2014) A comparison of regional monsoon variability using monsoon indices. Clim Dyn 43:1423-1437. https://doi.org/10. 1007/s00382-013-1956-9

Zhang Q, Xu CY, Zhang Z, Chen YD, Liu CL, Lin H (2008) Spatial and temporal variability of precipitation maxima during 1960-2005 in the Yangtze River basin and possible association with large-scale circulation. J Hydrol 353:215227. https://doi.org/10.1016/j.jhydrol.2007.11.023

Zhao L, Ma CM, Leipe C, Long TW, Liu KB, Lu HY, Tang LY, Zhang Y, Wagner M, Tarasov PE (2017) Holocene vegetation dynamics in response to climate change and human activities derived from pollen and charcoal records from southeastern China. Palaeogeogr Palaeoclimatol Palaeoecol 485:644-660

Zheng Y, Kissel C, Zheng HB, Laj C, Wang K (2010) Sedimentation on the inner shelf of the East China Sea: magnetic properties, diagenesis and paleoclimate implications. Mar Geol 268(1-4):34-42

Zhou TJ, Gong DY, Li J, Li B (2009) Detecting and understanding the multidecadal variability of the East Asian summer monsoon-recent progress and state of affairs. Meteorol Z 18:455-467

\section{Publisher's Note}

Springer Nature remains neutral with regard to jurisdictional claims in published maps and institutional affiliations.

\section{Submit your manuscript to a SpringerOpen ${ }^{\circ}$ journal and benefit from:}

- Convenient online submission

- Rigorous peer review

- Open access: articles freely available online

- High visibility within the field

- Retaining the copyright to your article

Submit your next manuscript at $>$ springeropen.com 